。相田美喜 (筑波大) ・ 伊藤一幸・石井康雄 (農環研) - 日井健二（筑波大）

近年、かつては防除の対象となっていた水田雑草の中からも絶滅危惧植物とされる種が認められて いるが、水生シダのオオアカウキクサ、サンショウモ、デンジソウ、ミズニラもそのような種である。 水田で使用される一発処理剤の主成分として過去 10 年間最も使用されてきたベンスルフロンメチル (BSM)がこれらの種に及ぼす影響を、水田雑草との混植ポット試験によって検討し、それぞれの種に おける感受性の程度を推測した。また、これらの植物の生育地における除草剤濃度の測定を行った。

\title{
<材料・方法>
}

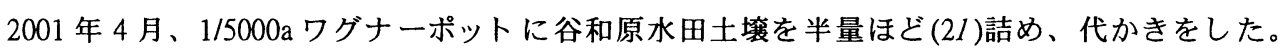

混植ポット (1) : 農環研で栽培した長野県坂城町産のデンジソウは、先端から約 $10 \mathrm{~cm}$ の長さの匍匐 茎を採集し、ポットあたり 2 本移植した。オオアカウキクサは、茨城県阿見町の蓮田水路で採集し、 農環研で増殖した胞子体を 5 個体ずつ移植した。比較種として、阿見町蓮田水路で採集したウキクサ、 コウキクサを 5 個体ずつ移植した。

混植ポット (2) : 農環研で增殖させた福井県敦賀市産のミズニラは、葉数が 10 前後の株をポットあ たり 5 個体移植した。阿見町蓮田水路で採集し、農環研で増殖させたサンショウモは幼胞子体を 10 個体ずつ移植し、同産地のイチョウウキゴケは比較種として 5 個体ずつ移植した。

5 月 11 日に、BSM 単剤を 75、25、7.5、2.5、0.75 g a.i./ha、0(無処理)となるように処理した。漏水の ない条件で、田面水が 7 $8 \mathrm{~cm}$ となるように管理した。経時的に生育調査を行い、調査最終日(約 1 ヶ 月後)に植物体を回収して乾燥させ $\left(80^{\circ} \mathrm{C} 、 48 \mathrm{~h}\right) 、$ 乾物重を測定した。

阿見町や土浦市の蓮田水路、休耕田、ため池などから、2001 年 5 月 2 日〜 6 月 27 日の期間中 $1 〜 2$ 週間ごとに採水した。ベンスルフロンメチル、ピラゾスルフロンエチル、メフェナセットの濃度を、 直接競合 ELISA を用いた免疫学的測定法(ヤトロン、大塚化学)によって測定した。

\section{<結果・考察 $>$}

混植ポット (1) デンジソウ、オオアカウキクサは BSM 処理量の增加に伴って顕著に生育が抑制さ れた(図1 )。ウキクサ類は、無処理区において競合によると思われる生育不良を示したが、2.5g a.i./ha 処理区において最も增殖し、75g a.i./ha 処理区においても生存していた。デンジソウ、オオアカウキク サの BSMに対する感受性はウキクサ類よりも高いものと推測された。

混植ポット(2) ミズニラは、75g a.i./ha 処理区で薬害症状が出たものの生育抑制の程度は小さかった。 サンショウモは、処理量の増加に伴って顥著な生育抑制を示した（図2）。イチョウウキゴケは薬剤処 理以外の要因による影響が大きく、感受性の程度を判断できなかった。

阿見町の蓮田水路におげる除草剤濃度は、いずれの剂についても、5月 23 日に最も高い值を示した (図3)。ポット試験における BSM 単剤処理との比較は難しいが、これらの除草剤がオオアカウキクサ やサンショウモの生育に影響を示す可能性があった。また、ため池、休耕田田面水からはいずれの除 草剤も検出されなかった。

混植ポット試験の結果から、オオアカウキクサ、サンショウモ、デンジソウは BSMに対する感受性 が高く、ミズニラは感受性が低いということが示唆された。また、オオアカウキクサ、サンショウモ が減少してきている阿見町の蓮田水路に、上流の水田から田植え後の一時期にいくつかの除草剂が流 出し、それらの生育に影響を及ぼしている可能性が示された。 
A デンジソウ

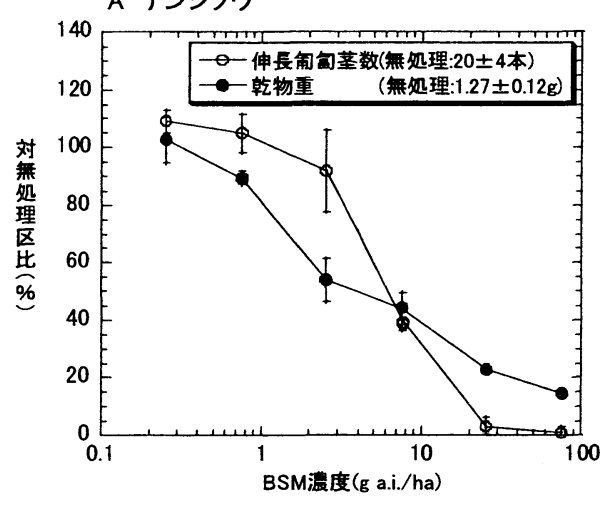

B オオアカウキクサ

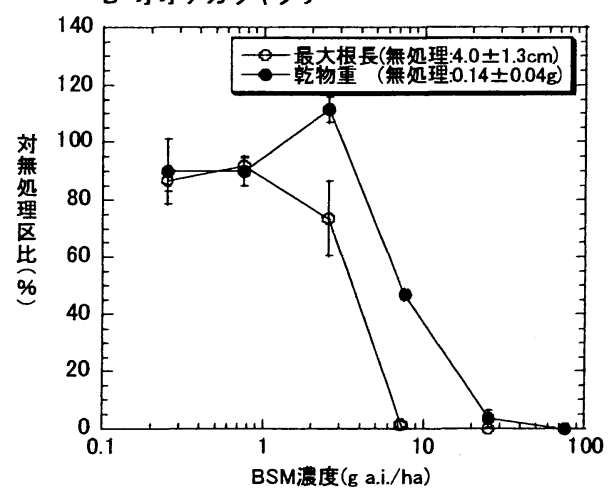

図1 混植ポツト(1)におけるデンジソウとオオアカウキクサの生育にBSM剤が及ぼす影響

A ミズニラ

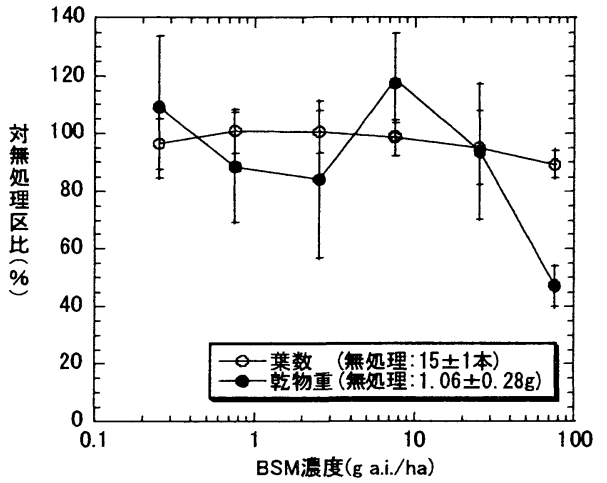

B サンショウモ

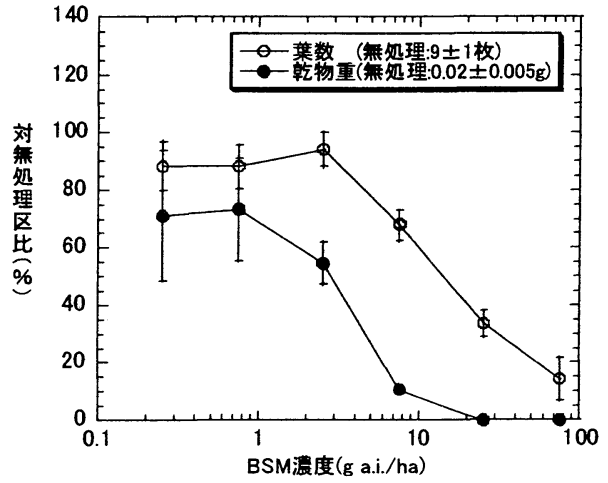

図2 混植ポット(2)におけるミズニラとサンショウモの生育にBSM凰が及ぼす影響

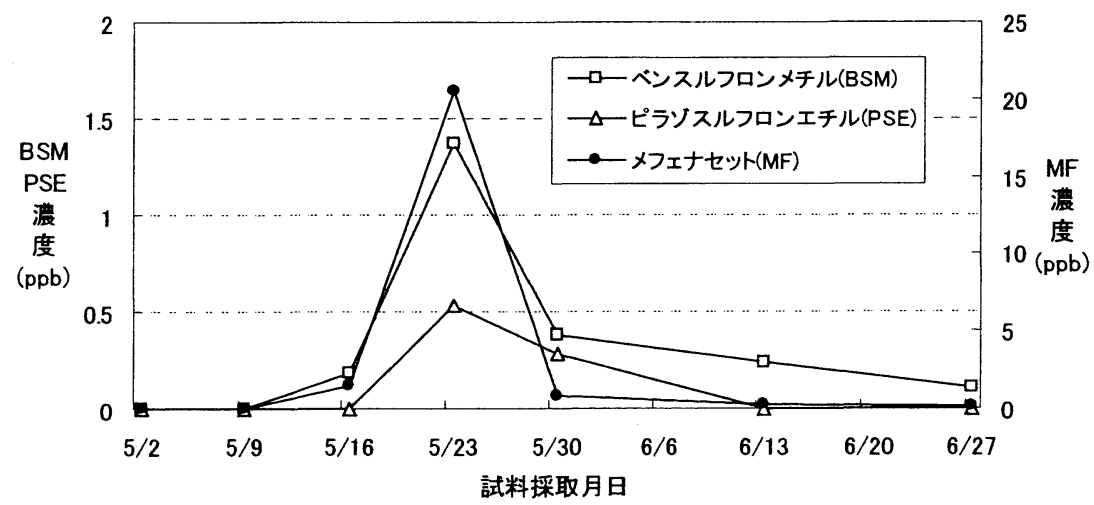

図3 蓮田水路における除草棛浱度の消長(2001年) 